\title{
Transient phlebitis: an unusual effect of intravenous diphenhydramine
}

\author{
Shashidhar N Manchegowda, ${ }^{1}$ Reine Zbeidy $\left({ }^{\circ},{ }^{2}\right.$ Fouad G Souki (i) ${ }^{2}$
}

${ }^{1}$ Anesthesiology, Jackson Memorial Hospital, Miami, Florida, USA

${ }^{2}$ Anesthesiology, University of Miami School of Medicine, Miami, Florida, USA

\section{Correspondence to}

Dr Fouad G Souki:

fsouki@med.miami.edu

Accepted 27 June 2020
Check for updates

(C) BMJ Publishing Group Limited 2020. No commercial re-use. See rights and permissions. Published by BMJ.

To cite: Manchegowda SN, Zbeidy R, Souki FG. BMJ Case Rep 2020;13:e237273. doi:10.1136/bcr-2020237273

\section{DESCRIPTION}

A 29-year-old man with no known allergies and end-stage renal disease due to IgA nephropathy presented for kidney transplantation. In the preoperative area, an $18 \mathrm{G}$ intravenous cannula was placed in the lateral dorsal side of the left hand cephalic vein. Immediately after intravenous injection of undiluted $1 \mathrm{~mL}$ of $50 \mathrm{mg}$ diphenhydramine hydrochloride (West-Ward Pharmaceuticals Eatontown, New Jersey, USA), patient developed transient burning pain and erythema in the volar and dorsal forearm tributaries of the cannulated vein (figure 1). The episode was not associated with itching, haemodynamic changes or signs of a systemic allergic reaction. We flushed the vein with a normal saline infusion and the erythema resolved after $30 \mathrm{~min}$. The patient was diagnosed with phlebitis based on the Infusion Nurses Society phlebitis scale. ${ }^{1-3}$ Anaesthesia was induced and maintained through the same intravenous cannula uneventfully. The patient denied any pain, lumps or hardening of the forearm veins during and after hospital stay.

Phlebitis is the inflammation of the internal lining, tunica intima, of a vein. It is associated with pain, swelling and erythema around the intravenous cannula insertion site or along the course of the vein without systemic involvement. ${ }^{4}$ In severe cases, it may lead to thrombosis of the vein which manifests as a small lump. Causative agents may be mechanical (size, location, composition of intravenous cannula), chemical (drugs, infusates) or biological (infections). Chemical phlebitis occurs when solutions with particulate matter, high concentration $(>10 \mathrm{mg} / \mathrm{mL})$ and high or low $\mathrm{pH}$ irritate veins. Old age, thin body habitus and atopic tendency have also been thought to increase incidence and severity. ${ }^{5}$

Transient phlebitis has been described after intravenous administration of several drugs (meperidine, morphine, rocuronium, propofol, eptifibatide and ciprofloxacin). ${ }^{5-10}$ Hypothesised mechanisms associated with this phenomenon include tissue damage, local mediator release, histamine release, direct activation of $\mathrm{C}$-nociceptors and activation of kallikrein-kinin system with bradykinin generation. $^{56}$

Diphenhydramine is an antihistamine ( $\mathrm{H}-1$ receptor antagonist) with anticholinergic and sedative effects. In the parenteral form, diphenhydramine hydrochloride is supplied at a concentration of $50 \mathrm{mg} / \mathrm{mL}$ and a $\mathrm{pH}$ of 4.0 to 6.5 that is adjusted with either sodium hydroxide or hydrochloric acid. It is recommended to be infused at a rate not exceeding $25 \mathrm{mg} / \mathrm{min} .{ }^{11}$ To the best of

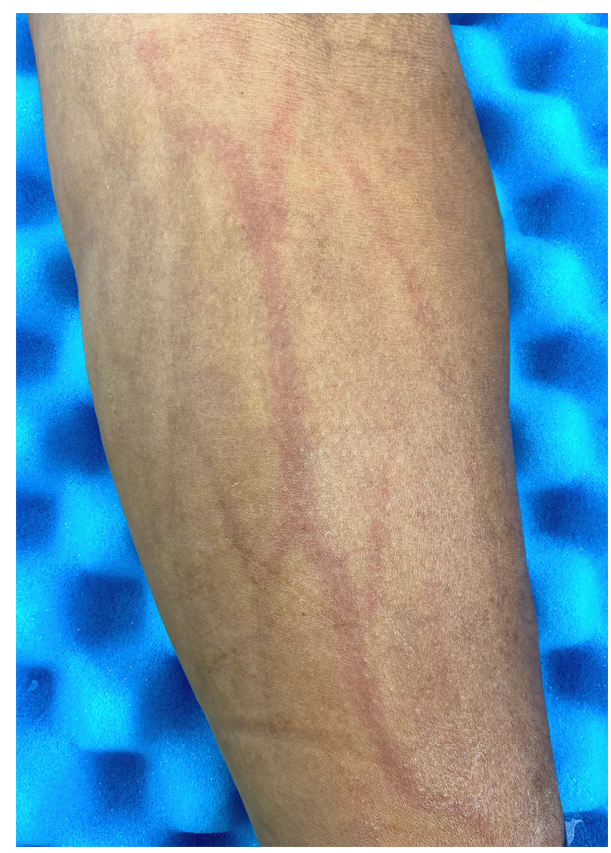

Figure 1 Erythema in the left forearm volar veins immediately after diphenhydramine injection.

\section{Learning points}

- Phlebitis is associated with pain, swelling and erythema along the course of a vein.

- Intravenous diphenhydramine can cause transient phlebitis.

- Appropriate drug dilution and slow infusion can decrease incidence.

our knowledge, there has not been any published reports, with pictorial evidence, of transient phlebitis caused by intravenous administration of diphenhydramine hydrochloride. Diluting diphenhydramine appropriately, infusing at recommended rate and using a large vein for infusion can prevent this side effect.

Contributors RZ was involved in writing and editing the manuscript. FGS and SM were involved in the care of the patient, writing and editing of the manuscript and the image.

Funding The authors have not declared a specific grant for this research from any funding agency in the public, commercial or not-for-profit sectors.

Competing interests None declared.

Patient consent for publication Obtained.

Provenance and peer review Not commissioned; externally peer reviewed. 
Images in...

\section{ORCID iDs}

Reine Zbeidy http://orcid.org/0000-0002-6963-885X

Fouad G Souki http://orcid.org/0000-0003-0895-5496

\section{REFERENCES}

1 Infusion Nurses Society. Phlebitis. J Infus Nurs 2016;39:S95-6.

2 Göransson K, Förberg U, Johansson E, et al. Measurement of peripheral venous catheter-related phlebitis: a cross-sectional study. Lancet Haematol 2017:4:e424-30.

3 Ray-Barruel G, Polit DF, Murfield JE, et al. Infusion phlebitis assessment measures: a systematic review. J Eval Clin Pract 2014;20:191-202.

4 Tagalakis V, Kahn SR, Libman M, et al. The epidemiology of peripheral vein infusion thrombophlebitis: a critical review. Am J Med 2002;113:146-51.

5 Krishnan P, Sultan A. An unusual reaction to IV pethidine-a case report. Br J Med Pract 2014;7:a707.
6 Eyigor C, Ceylan A, Demir F, et al. Superficial venous thrombophlebitis caused by rocuronium. J Anesth 2010;24:646-8.

7 Jain R, Jain P, CG S. An unusual side effect of intravenous morphine. Int J Med Res Prof 2016;2:92-3.

8 Shah A, Ong PY. Immediate superficial venous thrombophlebitis associated with intravenous administration of ciprofloxacin. J Pediatr 2018;200:289.

9 Kinoshita H, Kakutani T, Minonishi T, et al. Transient phlebitis induced by a bolus injection of propofol. J Anesth 2006;20:74-5.

10 Hay E, Blaer Y, Shlyakhover V, et al. Acute transient phlebitis during eptifibatide intravenous injection: case report. Heart Lung 2010;39:235-6.

11 Diphenhydramine hydrochloride injection. Available: https://dailymed.nlm.nih.gov/ dailymed/druglnfo.cfm?setid=ec691492-a295-4b48-a1a35824931efa97 [Accessed June 2020].

Copyright 2020 BMJ Publishing Group. All rights reserved. For permission to reuse any of this content visit https://www.bmj.com/company/products-services/rights-and-licensing/permissions/

BMJ Case Report Fellows may re-use this article for personal use and teaching without any further permission.

Become a Fellow of BMJ Case Reports today and you can:

Submit as many cases as you like

Enjoy fast sympathetic peer review and rapid publication of accepted articles

- Access all the published articles

Re-use any of the published material for personal use and teaching without further permission

Customer Service

If you have any further queries about your subscription, please contact our customer services team on +44 (0) 2071111105 or via email at support@bmj.com.

Visit casereports.bmj.com for more articles like this and to become a Fellow 